\title{
PERLINDUNGAN HUKUM TERHADAP PEMBELI BARANG BERGERAK YANG MASIH TERIKAT FIDUSIA MELALUI PEJABAT LELANG KELAS II DALAM RANGKA MEWUJUDKAN KEPASTIAN HUKUM
}

\author{
Khalidin \\ Notaris, PPAT dan Pejabat Lelang Kota Pekanbaru \\ e-mail: khalidin@gmail.com
}

\begin{abstract}
Abstrak-Lembaga lelang diatur dalam peraturan perundang-undangan khusus, guna memenuhi kebutuhan masyarakat akan lelang, dalam rangka memberikan perlindungan dan jaminan kepastian hukum dan kebutuhan dunia usaha pada umumnya, lelang termasuk perjanjian bernama (nominaat) diluar KUHPerdata, karena lelang mempunyai nama sendiri yaitu "lelang" (vendu reglement). Penelitian ini akan dilakukan tentang Perlindungan Hukum Kepada Pembeli Barang Bergerak terdaftar melalui Pejabat Lelang Kelas II dihubungkan dengan hak-hak pembeli. Bagaimanakah Tanggung Jawab Penjual, terhadap pembeli barang bergerak terdaftar yang tidak memperoleh hak-hak sebagai pembeli dihubungkan dengan kepastian hukum. Tanggung Jawab Pejabat Lelang Kelas II dalam melelang barang bergerak terdaftar, antara pemenang lelang dengan penjual. Penelitian ini menggunakan metode hukum normatif yang bersifat kualitatif. Bentuk penelitian deskriptif analitis. Hasil penelitian ini menunjukkan pertama, pembeli lelang terbukti beritikat baik, dengan mengiktuti prosedur dan mekanisme lelang dan juga membayar Pendapatan Negara Bukan Pajak sesuai dengan Peraturan pemerintah nomor 1 tahun 2013, oleh karena Indonesia sebagai Negara hukum telah memberikan kepastian dan perlindungan hukum kepada pembeli lelang, yang kewenangannya dijalankan oleh Pejabat lelang. Kedua, sebagai Negara hukum, Indonesia mengatur penjual bertanggung jawab terhadap barang miliknya yang akan dilelang guna memberikan jaminan kepastian hukum kepada pembeli, oleh karena itu Pejabat lelang pun tidak diberikan kewenangan untuk melelang barang-barang yang legalitasnya tidak sah, sebagaimana objek penelitian tersebut diatas. Untuk itu kiranya Penjual harus dibebani tanggung jawabnya guna memberikan ganti kerugian kepada pembeli barang lelang yang tidak dapat menguasai barang yang telah dibelinya dari lelang.
\end{abstract}

\section{Kata Kunci: Perlindungan Hukum, Pembeli, Fidusia, Pejabat Lelang, Kepastian Hukum.}

\begin{abstract}
The auction institution is regulated in a special legislation, in order to meet the needs of the public for the auction, in order to provide protection and guarantee of legal certainty and business needs in general, the auction includes a named agreement (nominaat) outside the Civil Code, since the auction has its own name "auction" (Vendu reglement). This research will be conducted on Legal Protection to Buyer of Registered Goods through Class II Auction Officials connected with buyer rights. How is the Seller's Responsibility, towards a registered buyer of goods that does not acquire the rights as a buyer associated with legal certainty. Responsibilities of Class II Auction Officials in auctioning of registered goods are listed, between the winning bidder and the seller. This research uses normative legal methods that are qualitative. Form of analytical descriptive research. The results of this study indicate firstly, the buyer of the auction is proven to be well-informed, by following the procedure and auction mechanism and also paying Non-Tax State Revenue in accordance with Government Regulation No. 1 of 2013,
\end{abstract}


Khalidin, Perlindungan Hukum Terhadap Pembeli Barang Bergerak Yang Masih Terikat Fidusi...

since Indonesia as a State of law has provided legal certainty and protection to the auction buyer, whose authority is exercised by the auction Officer. Secondly, as a rule of law, Indonesia shall arrange the seller to be responsible for his property to be auctioned in order to provide assurance of legal certainty to the buyer, therefore the auction officer shall not be authorized to auction off illegally legitimate goods, as the object of the research mentioned above. For that Seller should be burdened with responsibility to provide compensation or a refund to buyers of auction goods that can not control the goods that have been purchased from the auction.

Keywords: Legal Protection, Buyer, Fiduciary, Auction Officer, Legal Certainty.

\section{A. PENDAHULUAN}

Istilah lelang berasal dari bahasa Belanda, yaitu Vendu, sedangkan dalam bahasa Inggris, disebut dengan istilah auction, pengertian lelang dapat dilihat dan dibaca di dalam peraturan perundangundangan yang berkaitan dengan lelang dan pandangan para ahli (Salim H.S, 2014:237).

Di Indonesia hanya ada dua pejabat lelang sebagaimana telah diatur dalam Vendu Reglement dan Vendu Instructie, bahkan secara khusus telah diatur dalam Pasal 8 ayat

(1) PMK Nomor 93/PMK.06/2010, yang menyatakan bahwa Pejabat Lelang terdiri dari: pertama, Pejabat Lelang Kelas I; dan kedua, Pejabat Lelang Kelas II.

$$
\text { Pejabat Lelang Kelas I }
$$
merupakan pejabat lelang pegawai Direktorat Jenderal Kekayaan Negara yang berwenang melaksanakan Lelang eksekusi, non eksekusi wajib, dan Lelang non eksekusi sukarela, demikian ketentuan PMK Nomor 174/PMK.06/2010. Pasal 1 ayat 2 PMK Nomor 175/PMK.06/2010, mengatur bahwa pejabat Lelang Kelas II adalah pejabat lelang swasta yang berwenang melaksanakan Lelang non eksekusi sukarela.

Dalam pengertian Pejabat Lelang Kelas I dan Pejabat Lelang Kelas II diatas, dengan penekanan dan penegasan adanya unsur "yang berwenang", berarti kedua pejabat lelang diberikan kewenangan tersendiri untuk melaksanakan tugas pekerjaannya, dan oleh karena itu "wewenang merupakan bagian yang sangat penting dan bagian awal dari hukum administrasi, karena pemerintahan (administrasi) baru dapat menjalankan fungsinya atas 
Khalidin, Perlindungan Hukum Terhadap Pembeli Barang Bergerak Yang Masih Terikat Fidusi...

dasar wewenang yang diperolehnya, artinya keabsahan tindakan pemerintahan atas dasar wewenang yang diatur dalam Peraturan Perundang-Undangan (legalitiet beginselen) (Sadjijono, 2011:56-61). Pejabat Lelang Kelas II berwenang melaksanakan lelang Noneksekusi Sukarela sesuai Pasal 12 Peraturan Menteri Keuangan Nomor 175/PMK.06/2010 menyatakan Pejabat Lelang Kelas II berwenang melaksanakan lelang atas permohonan Balai Lelang dan penjual/pemilik barang. Pelaksanaan lelang oleh Pejabat Lelang Kelas II terbatas pada lelang non eksekusi Sukarela termasuk tetapi tidak terbatas pada lelang milik BUMN/D berbentuk persero, lelang harta milik bank dalam likuidasi kecuali ditentukan lain oleh peraturan Perundang-Undangan. Lelang barang milik perwakilan negara asing dan lelang barang milik swasta.

Seorang pejabat lelang dalam melaksanakan kewenangannya sudah pasti diminta pertanggung jawaban, oleh karena itu, maka tanggung jawab Vendumeester disebut juga pejabat lelang. Tanggung jawab dan segala sesuatu yang ditentukan dalam Peraturan-Peraturan dan InstruksiInstruksi lelang untuk tiap-tiap Vendumeester K1. I umumnya berlaku juga sepenuhnya terhadap para Vendumeester K1. II yang diangkat dalam bentuk baru ini, dan kemudian dijabarkan dalam beberapa Vendu Reglement.

\section{Purnama Tioria Sianturi} menyatakan bahwa mengkaji tanggung jawab kantor lelang, perlu dikaitkan dengan posisi Pejabat Lelang sebagai Pejabat Umum, karena Pejabat Lelang membuat akta otentik berupa Risalah Lelang yang memenuhi unsur-unsur akta otentik sebagaimana diatur oleh Pasal 1868 dan 1870 Kitab Undang-Undang Hukum Perdata (Purnama T. Sianturi, 2013:125).

Berdasarkan uraian diatas, maka Pejabat Lelang juga disebut sebagai Pejabat Umum, karena pengertian seorang menjadi Pejabat Umum apabila ia diangkat dan diberhentikan oleh Pemerintah, diberi wewenang dan kewajiban untuk melayani publik dalam hal-hal tertentu, karena itu ia ikut serta melaksanakan kewibawaan (gezag) 
Khalidin, Perlindungan Hukum Terhadap Pembeli Barang Bergerak Yang Masih Terikat Fidusi...

dari Pemerintah. Dijelaskan bahwa lelang juga merupakan jual beli (auction) atau disebut juga "penjualan umum" (openbare verkopingen), dan fokus pada tulisan ini adalah "Perlindungan Hukum Terhadap Pembeli Barang Bergerak Yang masih Terikat Fidusia Melalui Pejabat Lelang Kelas II Dalam Rangka Mewujudkan Kepastian Hukum

Berdasarkan latar belakang diatas, maka identifikasi masalah dari penelitian ini adalah Bagaimanakah Perlindungan Hukum Kepada Pembeli Barang Bergerak terdaftar melalui Pejabat Lelang Kelas II dihubungkan dengan hak-hak pembeli?; Bagaimanakah Tanggung Jawab Penjual, terhadap pembeli barang bergerak terdaftar yang tidak memperoleh hak-hak sebagai pembeli dihubungkan dengan kepastian hukum?; Bagaimanakah Tanggung Jawab Pejabat Lelang Kelas II dalam melelang barang bergerak terdaftar, antara pemenang lelang dengan penjual?

Penelitian ini menggunakan metode hukum normatif yang bersifat kualitatif. Bentuk penelitian deskriptif analitis. Dengan pertimbangan jumlah kasus yang terjadi dalam setiap lelang, maka penulis meneliti tiga kasus lelang di Pekanbaru. Data penelitian dikumpulkan dengan studi dokumen/kepustakaan, orientasi utama pada penelitian kepustakaan adalah bahan hukum primer, sekunder dan tersier.

\section{B. HASIL DAN PEMBAHASAN}

1. Perlindungan

Hukum

\section{Kepada Pembeli Barang}

Bergerak Terdaftar

MelaluiPejabat Lelang Kelas

IIDihubungkan Dengan Hak-

\section{Hak Pembeli}

Pembahasan

tentang

perlindungan hukum, dititik beratkan bagi pembeli barang bergerak terdaftar melalui Pejabat Lelang Kelas II, hal ini disebabkan karena pembeli lelang yang telah memenangkan lelang barang bergerak terdaftar tersebut, kurang mendapat perlindungan hukum, sehingga sewaktu-waktu dapat saja kehilangan pendapatannya yang diharapkan dari jual beli barang bergerak berupa mobil dimaksud, kenyataan ini menunjukkan ketidak seimbangan kedudukan para pihak yaitu, pihak 
Khalidin, Perlindungan Hukum Terhadap Pembeli Barang Bergerak Yang Masih Terikat Fidusi...

penjual dan pihak pembeli dalam pelaksanaan lelang, adalah seorang suatu lelang barang bergerak. yang membeli barang dengan Sehingga perlu dipertanyakan kejujuran penuh kepercayaan bahwa Jaminan perlindungan hukumnya.

Purnama Tioria Sianturi sepenjual benar-benar pemilik mengatakanbahwa itikad baik menyangkut dimensi yang pertama yaitu dimensi subyektif yang berarti itikad baik mengarah pada makna kejujuran dan dimensi kedua adalah dimensi obyektif yang memaknai itikad baik mengenai kerasionalan, kepatutan atau keadilan. Itikad baik dalam kontek Pasal 1338 (ayat 3) Kitab Undang-Undang Hukum Perdata harus didasarkan pada kerasionalan dan kepatutan. Itikad baik pra kontrak tetap mengacu pada itikad baik yang bersifat subjektif, yang digantungkan pada kejujuran para pihak. Dalam proses negosiasi dan penyusunan kontrak, pihak kreditur memiliki kewajiban untuk menjelaskan fakta materil yang berkaitan dengan pokok yang dinegosiasikan, sedangkan debitur berkewajiban meneliti fakta materil tersebut. Seorang pembeli lelang yang beritikad baik berhubungan dengan dimensi subjektif yang harus ada dalam pra kontrak/sebelum barang, pembeli yang beritikad baik adalah orang yang memiliki kejujuran yang tidak mengetahui adanya cacat yang melekat pada barang yang dibelinya itu, artinya cacat mengenai asal-usulnya.

Seorang pembeli lelang yang beritikad baik dengan dimensi kedua/dimensi objektif adalah dimensi yang memaknai itikad baik pembeli lelang mengenai kerasionalan, kepatutan atau keadilan. Dalam proses negosiasi dan penyusunan kontrak, yaitu penjual memiliki kewajiban untuk menjelaskan fakta materil yang berkaitan dengan pokok yang dijual, sedangkan debitur, dalam hal ini pembeli lelang berkewajiban meneliti fakta materil tersebut.

Pembeli barang tidak bergerak melalui pelelangan (jual beli khusus) yang berasal dari barang jaminan atau agunan hutang pada Lembaga Keuangan Bank atau non Bank yang merupakan kreditur atau bank separatis, bahkan lebih parah lagi 
Khalidin, Perlindungan Hukum Terhadap Pembeli Barang Bergerak Yang Masih Terikat Fidusi...

setelah pembeli/pemenang lelang akta otentik sebagaimana ingin menguasai barang lelang dimaksudkan dalam Pasal 1868 Kitab tersebut berupa tanah dan bangunan, Undang-Undang Hukum Perdata, dan ternyata pemiliknya tidak bersedia dalam Pasal 1870 dan 1871 Kitab pindah atau mengosongkan tanah dan Undang-Undang Hukum Perdata bangunan, sehingga pembeli/ merupakan alat pembuktian yang pemenang lelang harus menempuh upaya-upaya lainnya, termasuk upaya hukum lain yaitu meminta bantuan kepolisian untuk mengosongkan tanah dan bangunan tersebut, dan akhirnya pembeli lelang menjadi tidak tenang dan ragu-ragu membeli barang lelang, karena tidak memberikan kepastian hukum dan barangnya tidak terjamin, padahal harapan atau keinginan pembeli lelang, begitu dimenangkan lelang maka dengan serta merta dapat memiliki dan menguasai tanah dan bagunan dimaksud, sehingga pembeli lelang tidak menimbulkan keraguraguan terhadap barang yang akan dibelisecara lelang dari pelelangan tersebut.

Akan tetapi kepastian hukum merupakan keuntungan yang diberikan dalam jual beli secara lelang, oleh karena Pejabat Lelang membuat dan membekalinya dengan akta Risalah Lelang yang merupakan sempurna bagi para pihak yang terkait langsung atau tidak langsung, hal tersebut bermakna bahwa kebenaran dari hal-hal yang tertulis dan harus berhubungan langsung dengan pokok isi akta dianggap sebagai benar, selama kebenaran itu tidak ada pihak lain yang dapat membuktikan sebaliknya.

Penjelasan diatas telah memberi bukti yang cukup bahwa adanya jaminan kepastian hukum, meskipun harus bersusah payah menempuh upaya hukum lainnya dan banyak mengeluarkan biaya. Ironisnya secara faktual seakan-akan perlindungan hukum lebih melindungi pemilik barang, sehingga adanya anggapan ketidakpastian hukum pada pembeli ini, hal tersebut tercermin dari salah satu klausula Risalah Lelang yang menyatakan bahwa barang-barang yang dilelangberupa apa adanya (As $I s)$. 
Khalidin, Perlindungan Hukum Terhadap Pembeli Barang Bergerak Yang Masih Terikat Fidusi...

Menurut penulis penjualan atau lelang barang-barang bergerak terdaftar secara apa adanya (As Is) lebih dititik beratkan pada cacat tersembunyi (cacat fisik), ini adalah suatu bentuk pengecualian yang dibenarkan dalam jual beli lelang, namun apabila cacat secara yuridis, maka pemilik barang terdaftar dan Pejabat Lelang Kelas II harus bertanggung jawab untuk menanggung ganti kerugian sesuai Pasal 1365, 1366 Kitab UndangUndang Hukum Perdata.

Dengan tidak adanya pengaturan secara limitatif dalam suatu Undang-Undang, tentang jaminan kepastian hukum kepada pembeli/pemenang lelang barang bergerak terdaftar, meskipun dalam Undang-Undang Dasar 1945 dan beberapa norma atau kaedah yurisprudensi Mahkamah Agung Republik Indonesia tentang pembeli yang beritikad baik, telah menyahuti kekosongan hukum guna memberikan jaminan kepastian hukum kepada pembeli lelang barang bergerak terdaftar.

Indonesia sebagai Negara hukum, telah mengatur bahwa penjual harus bertanggung jawab terhadap barang miliknya yang akan dilelang guna memberikan jaminan kepastian hukum kepada pembeli, oleh karena itu Pejabat lelang pun tidak diberikan kewenangan untuk melelang barang-barang yang legalitasnya tidak sah, sebagaimana objek penelitian tersebut diatas. Untuk itu kiranya Penjual harus dibebani tanggung jawabnya guna memberikan ganti kerugian kepada pembeli barang lelang yang tidak dapat menguasai barang yang telah dibelinya dari lelang.

Demikian juga kewenangan melelang oleh Pejabat Lelang Kelas II sudah terpenuhi, karena barangbarang bergerak yang menjadi obyek lelang, pendaftaran fidusianya telah diroya (dihapus) dengan sempurna sesuai dengan petunjuk undangundang nomor 42 tahun 1999, untuk itu lah maka pembeli lelang barangbarang bergerak terdaftar yang merupakan obyek lelang atau jual beli khusus tidak perlu diragukan keabsahannya, karena ketentuan dan konstruksi hukum sudah jelas dan pasti memberikan jaminan kepastian hukum. 
2. Tanggung Jawab Penjual

Kepada Pembeli Barang

Bergerak Terdaftar Yang

Tidak Memperoleh Hak-Hak

Pada Umumnya Sebagai

Pembeli

Pada jual beli melalui lelang, maka penjual tidak bertanggung jawab tentang adanya cacat tersembunyi, penegasan itu dituangkan dalam Risalah Lelang, sebagai berikut: "Penawar/ pembeli dianggap sungguh-sungguh telah mengetahui apa yang telah ditawarkan olehnya, apabila terdapat kekurangan/kerusakan baik yang terlihat ataupun yang tidak terlihat, maka penawar/ pembeli tidak berhak untuk menolak atau menarik diri kembali, setelah pembelian disahkan dan melepaskan segala hak untuk meminta kerugian atas suatu apapun juga".

Tetapi dalam jual beli biasa, maka tidak dibenarkan adanya cacat tersembunyi pada barang yang dijual, kalaupun cacat tersembunyi itu terjadi merupakan tanggung jawab dari penjual, karena penjual harus menjamin tidak adanya cacat tersembunyi tersebut. Menurut
Hartono Soerjopratiknjo penjual harus juga menjamin tidak adanya cacat tersembunyi pada barang yang dijual. Cacat itu harus menjadikan barang itu tidak dapat digunakan untuk tujuannya, atau mengurangi penggunaannya sedemikian rupa, sehingga seandainya pembeli mengetahui adanya cacat itu ia tidak akan membelinya, atau setidaktidaknya tidak akan bersedia membayar harga yang telah disepakati, apakah penjual mengetahui adanya cacat itu adalah tidak penting. Tapi mungkin saja para pihak telah memperjanjikan bahwa penjual tidak menanggung cacat yang tidak diketahui sendiri oleh penjual.

Yang dapat dipersoalkan adalah: apa yang dimaksud dengan cacat tersembunyi dan bagaimana sifat tuntutan berdasarkan adanya cacat tersembunyi itu. UndangUndang hanya mengatakan bahwa penjual tidak perlu menanggung cacat yang terlihat dan dapat diketahui oleh pembelinya.

Untuk dapat menuntut berdasarkan cacat tersembunyi, maka cacat itu harus menjadikan barang itu tidak dapat digunakan atau 
Khalidin, Perlindungan Hukum Terhadap Pembeli Barang Bergerak Yang Masih Terikat Fidusi...

mengurangi kemungkinan

penggungaannya. "Penggunaan"

diartikan sempit dalam arti materialistis. Jadi kesalahan dalam materi, pecah, sobek, patah, rusak, juga kayu yang jelek, besi yang jelek dapat merupakan cacat tersembunyi apabila itu mempengaruhi penggunaan, misalnya pisaunya ternyata dari besi lunak dan bukan dari baja. Juga pada benda tidak bergerak dapat ada cacat, kakusnya jika pada musim hujan meluap. pada benda tidak berwujud: obligasi tidak ada kuponnya.

Karena menurut penulis, keabsahan suatu barang sangat berbeda dengan cacat tersembunyi, kalau cacat tersembunyi adalah cacat fisik kenderaaan atau barang dan tidak terkait langsung dengan legalitas yuridis (keabsahan kepemilikan barang), dan bisa juga mengurangi nilai barang karena tidak sempurna, dan cacat tersembunyi dalam dunia lelang dibenarkan dan tetap dikesampingkan cacat tersembunyi, yaitu dengan adanya klausul "Pemilik barang tidak bertanggung jawab atas adanya cacat tersembunyi”, dan disinilah letak kekhususan lelang tersebut, sebab barang-barang dilelang dengan klausul "As Is" (apa adanya) akan tetapi keabsahan suatu mobil sebagai obyek lelang terletak pada adanya Buku Pemilik Kendaraan Bermotor atau untuk alat berat adanya faktur, yang harus sesuai kriterianya yang ada pada spesifikasi barang.

Maksudnya yang sangat esensial harus ada Buku Pemilik Kendaraan Bermotor, dan apa saja spesifikasi yang tertulis pada Buku Pemilik Kendaraan Bermotor harus ada kesesuaian specnya, karena apabila tidak sesuai spect berarti legalitas yuridis tidak terjamin (tidak lengkap) yang berakibat hukum mobil yang dilelang ini bodong atau tidak dapat dipertanggung jawabkan keabsahan obyek lelang. artinya "Penjual harus bertanggung jawab terhadap keabsahan kepemilikan barang".

Namun demikian terhadap barang yang dilelang dan masih tersangkut dalam suatu proses perkara tindak pidana dan belum memperoleh kekuatan hukum yang tetap, seharusnya finance (pemilik barang) harus berterus terang dengan balai 
Khalidin, Perlindungan Hukum Terhadap Pembeli Barang Bergerak Yang Masih Terikat Fidusi...

lelang dan Pejabat Lelang Kelas II, hatinya" yang mengaturmaka sebelum pelaksanaan lelang berkewajiban bertanggung jawab berlangsung tentang status obyek untuk menyelesaikan dan mengganti lelang, bahwa mobil tersebut seluruh biaya yang sudah dikeluarkan memiliki Buku Pemilik Kendaraan oleh pembeli lelang ini adalah Bermotor, dan seluruh spesifikasi sebagai bentuk perlindungan hukum yang tercantum pada fisik kenderaan tersebut sesuai dengan data BPKB.

Akan tetapi yang sangat mengejutkan kita bahwa pemilik barang telah membuat suatu pernyataan secara tertulis, yang menyatakan bahwa barang-barang yang akan dilelang tersebut tidak tersangkut dengan jaminan hutang atau perkara apapun. Ironisnya beberapa hari kemudian timbul permasalahan tersebut, hal ini membuktikan bahwa pemilik mobil telah memberikan keterangan atau pernyataan palsu kepada Pejabat Lelang Kelas.

Oleh karena itu penjual/ pemilik barang telah memenuhi ketentuan Pasal 1366 Kitab UdangUndang Hukum perdata "Setiap orang bertanggung jawab tidak saja untuk kerugian yang disebabkan karena perbuatannya, tetapi juga untuk kerugian yang disebabkan karena kelalaian atau kurang hatikepada pembeli lelang. Sebagai Negara hukum, Indonesia mengatur penjual bertanggung jawab terhadap barang miliknya yang akan dilelang guna memberikan jaminan kepastian hukum kepada pembeli, oleh karena itu Pejabat lelang pun tidak diberikan kewenangan untuk melelang barangbarang yang legalitasnya tidak sah, sebagaimana objek penelitian tersebut diatas.

\section{Tanggung Jawab Pejabat} Lelang Kelas IIDalam Melelang Barang Bergerak Terdaftar, Jika Terjadi Sengketa Antara Pemenang Lelang Dengan Penjual

Tanggung Jawab Pejabat Lelang Kelas II atas Pelaksanaan lelang yang dilakukan dihadapannya dapat berupa:

a. Segala Perselisihan yang mungkin timbul pada saat pelaksanaan lelang ini akan diselesaikan dan 
Khalidin, Perlindungan Hukum Terhadap Pembeli Barang Bergerak Yang Masih Terikat Fidusi...

diputuskan pada hari ini juga oleh saya Pejabat Lelang Kelas II.

Ini berarti bentuk pertanggung jawaban Pejabat Lelang untuk menyelesaikan persoalan lelang adalah harus pada hari pelaksanaan lelang. Namun Permasalaan ini timbul bukan pada saat pelaksanaan lelang, tetapi setelah selesai pelaksanaan lelang, dimana pada saat pendaftaran Balik nama pada Kantor Satuan Manunggal Satu Atap Pekanbaru, secara yuridis formal tugas dan tanggung jawab Pejabat Lelang Kelas II sudah selesai, karena permasalahan ini muncul bukan pada hari pelaksanaan lelang. Tetapi secara moral Pejabat Lelang Kelas II tetap bertanggung jawab untuk menyelesaikan permasalahan ini, termasuk melakukan mediasi dengan jalan musyawarah, sampai masalah tersebut benar-benar tuntas. Namun yang pasti kekeliruan pejabat lelang bukan terletak pada keadaan fisik obyek lelang, tetapi semata-mata terletak pada legalitas yuridis yaitu keabsahan barang yang tidak dimiliki.
Persoalan yang sangat mendasar terjadi pada saat pelaksanaan lelang berlangsung, dan peserta lelang sebenarnya sudah mengetahui permasalahan pada unit mobil yang akan dilelang tersebut, karena dalam daftar lot. Sudah tertera catatan khusus untuk mobil-mobil bermasalah, karena dikhawatirkan setelah pemenang lelang memenangkan mobil dimaksud, akan melakukan protes/ sanggahan/ keberatan, namun hal ini tetap tidak terjadi, sebelum dicoba untuk diproses di kantor Satuan Manunggal Satu Atap. Apabila petugas kantor Satuan Manunggal Satu Atap. mempermasalahkan mobil dimaksud dan menolak untuk diproses, maka diajukan sanggahan atau keberatan kepada pemilik barang dan pada akhirnya pemilik mobil menerima pengembalian mobil tersebut dengan cara "dibeli kembali".

Namun dalam objek penelitian ini, karena pejabat lelang tidak melaksanakan kewajibannya sebagaimana dimaksudkan dalam Pasal 13 PMK 
Khalidin, Perlindungan Hukum Terhadap Pembeli Barang Bergerak Yang Masih Terikat Fidusi...

175/2010 antara lain mengatur, Pejabat lelang berwenang menolak melaksanakan lelang dalam hal tidak yakin akan kebenaran formal berkas persyaratan lelang, yuncto Pasal 14 PMK 175/2010, antara lain mengatur, Pejabat lelang dalam melaksanakan jabatannya berkewajiban meneliti legalitas formal subjek dan objek lelang, yuncto Pasal 16 Peraturan Menteri Keuangan nomor: PMK 93/PMK.06/2010, Penjual/pemilik barang bertanggung jawab antara lain terhadap:

1) Keabsahan kepemilikan barang;

2) Keabsahan dokumen persyaratan lelang;

3) Penyerahan barang;

4) Dokumen kepemilikan kepada pembeli.

b. Pejabat Lelang Kelas II tidak menanggung atas kebenaran keterangan-keterangan yang diberikan secara lisan pada waktu penjualan tentang keadaan sesungguhnya dan keadaan hukum atas barang yang dilelang tersebut seperti perjanjian sewa-menyewa dan lain-lain dalam hal ini seluruhnya merupakan beban dan resiko pembeli.

Maksud dari pernyataan diatas, adalah dimana biasanya petugas-petugas (baik security, petugas pengawas dan lain-lain) dilapangan atau digudang tempat barang bergerak itu berada, pada waktu open house selalu dipertanyakan oleh pengunjung tentang keadaan barang bergerak tersebut, barangkali mereka memberikan keteranganketerangan, maka keterangan yang diberikan, secara hukum tidak dapat dipertanggung jawabkan, karena penjual/pemilik barang tidak memberikan kewenangan kepada petugas tersebut, untuk melayani pertanyaan-pertanyaan pengunjung atau calon pembeli/peserta lelang yang menyangkut obyek lelang. Pengunjung atau calon pembeli/peserta lelang harus melihat, mengamati dan menganalisa sendiri-sendiri tentang keadaan atau kondisi barang bergerak terdaftar tersebut.

Artinya kesalahan atau keliru dalam melakukan analisa 
Khalidin, Perlindungan Hukum Terhadap Pembeli Barang Bergerak Yang Masih Terikat Fidusi...

merupakan beban dan resiko pembeli. Sedangkan daftar lot yang ada merupakan pedoman saja dan tidak mengikat. Tetapi kebenaran yang dapat dipertanggung jawabkan adalah kondisi strategis yang real atau keadaan barang bergerak terdaftar itu sendiri sesuai keadaan di lapangan. Sedangkan keadaan hukum seperti sewa menyewa, misalnya barang bergerak terdaftar tersebut sebelum dilelang pernah disewakan oleh pemegang sewa beli sebelumnya kepada pihak ketiga, kemudian karena angsurannya tidak dibayar, maka barang bergerak dimaksud ditarik oleh finance (pemilik mobil) dan kemudian dilelang oleh Pejabat Lelang Kelas II.

Keadaan hukum atas obyek lelang tersebut, menurut penulis sesungguhnya merupakan tanggung jawab penjual, meskipun dalam klausula Risalah Lelang juga dituliskan. Ini juga merupakan kesalahan pemerintah melepaskan tanggung jawabnya. Menurut Purnama
Tioria Sianturi bahwa klausul tersebut mencerminkan pemerintah melepaskan tanggung jawab dari keadaan fisik maupun keadaan hukum barang yang dijual (Purnama Tioria Sianturi, 2013:119).

c. Penawar/pembeli di anggap sungguh-sungguh telah mengetahui apa yang telah ditawarkan olehnya, apabila terdapat kekurangan/kerusakan baik yang terlihat ataupun yang tidak terlihat, maka penawar/pembeli tidak berhak untuk menolak atau menarik diri kembali, setelah pembelian disahkan dan melepaskan segala hak untuk meminta kerugian atas suatu apapun juga.

Menurut Purnama Tioria Sianturi, Klausul tersebut menyatakan bahwa "Kekurangan dan Kerusakan yang terlihat", "Kekurangan dan kerusakan yang tidak terlihat" dan "Cacat lainnya" bukanlah tanggung jawab Kantor Lelang/Pemerintah, klausulklausul tersebut seakan-akan merugikan pembeli lelang, terutama yang tidak melakukan 
Khalidin, Perlindungan Hukum Terhadap Pembeli Barang Bergerak Yang Masih Terikat Fidusi...

pemeriksaan barang sebelum membeli atau yang awam terhadap penjualan lelang. Isi klausul tersebut menyatakan Pejabat lelang tidak menanggung kebenaran keterangan yang diberikan pada waktu penjualan, semuanya resiko pembeli atau keterangan itu hanya pasti antara pihak-pihak sendiri (pembeli dan penjual) (Purnama Tioria Sianturi, 2013:119).

Disamping tanggung jawab Pejabat Lelang Kelas II sebagaimana telah disebut diatas, maka Pejabat Lelang tetap bertanggung jawab menjembatani sebagai penengah antara pemenang lelang dengan Penjual (Pemilik barang). Dan berdasarkan klausulklausul dimaksud, untuk memperjelas dimanakah bentuk tanggung jawab Pejabat Lelang Kelas II, maka untuk itu perlu dilakukan penafsiran yang acontrario atau penafsiran terbalik, khusus untuk nomor urut 2 . Artinya Pejabat Lelang tetap bertanggung jawab memberikan penjelasan atas keterangan yang diberikan secara tertulis dan resmi, namun apabila ada persoalan terhadap objek lelang yang pernah dilakukan perbuatan hukum dalam bentuk lain sebelum barang lelang ini sampai ketangan Pejabat Lelang Kelas II untuk dilelang, maka itu semua menjadi beban dan tanggung jawab pembeli.

Menurut penulis pejabat lelang sebagai pejabat umum yang diangkat dan diberikan kewenangan oleh pemerintah, sudah pasti sangat mengetahui tentang legalitas atau keabsahan barang yang dilelang sebagaimana disebut dalam Pasal 16 (ayat 1.a) PMK nomor 93/PMK.06/2010, tentang petunjuk pelaksanaan lelang, antara lain disebutkan, Penjual/Pemilik Barang bertanggung jawab terhadap "Keabsahan kepemilikan barang" meskipun tidak disebut secara lebih rinci apa yang dimaksudkan dengan "keabsahan kepemilikan barang", oleh karena itulah maka untuk tidak menimbulkan multi tafsir terhadap ketentuan "keabsahan kepemilikan barang", perlu diatur secara lebih rinci dalam penjelasan undang-undang 
Khalidin, Perlindungan Hukum Terhadap Pembeli Barang Bergerak Yang Masih Terikat Fidusi...

lelang, tentang apa yang dimaksud dengan "keabsahan kepemilikan barang", tersebut. Pejabat lelang tidak hanya dapat dibebani sanksi administratif tetapi juga dapat dibebani tanggung jawabnya terhadap pihak ketiga, untuk menanggung kerugian secara renteng antara pejabat lelang, balai lelang dan pembeli lelang, sebab sebagai pejabat lelang yang ahli dibidang lelang tidak melaksanakan kewajibannya sesuai ketentuan Peraturan Menteri Keuangan tersebut.

Khusus untuk nomor urut 3 , Pejabat lelang bertanggung jawab memberikan penjelasan tentang kepastian bahwa setiap peserta lelang harus sungguh-sungguh telah mengetahui apa yang telah ditawarkan olehnya, apabila terdapat kekurangan/kerusakan baik yang terlihat ataupun yang tidak terlihat (cacat tersembunyi), maka penawar/pembeli tidak berhak untuk menolak atau menarik diri kembali, setelah pembelian disahkan dan melepaskan segala hak untuk meminta kerugian atas suatu apapun juga. Dari rumusan tersebut diatas, sangat jelas bahwa tanggung jawab Pejabat Lelang Kelas II, hanya sebatas pada kewajiban membacakan risalah lelang dihadapan peserta lelang dan kalau terjadi perselisihan pada saat pelaksanaan lelang, maka Pejabat Lelang Kelas II harus menyelesaikan pada hari itu juga sebagai bentuk tanggung jawabnya pejabat lelang, tetapi kalau terjadi permasalahan pada obyek lelang yang telah dimenangkan dikemudian hari, maka diluar tanggung jawab Pejabat Lelang Kelas II.

Sedangkan urgensi pengaturannya keharusan para pelaku lelang di indonesia, dimaksudkan agar penjual atau pemilik barang, balai lelang dan Pejabat Lelang Kelas II dapat memahami hak dan kewajiban dalam konteks pelaksanaan lelang yang akan diatur dalam suatu Undang-Undang di Indonesia. Demikian juga apabila terjadi sengketa akan memudahkan penyelesaiannya, seperti tercermin dalam tiga kasus tersebut diatas. 
Khalidin, Perlindungan Hukum Terhadap Pembeli Barang Bergerak Yang Masih Terikat Fidusi...

Meskipun ketiga kasus tersebut akhirnya dapat diselesaikan dengan jalan musyawarah dan mufakat. Namun ini adalah awal dari permasalahan yang akan dijadikan dasar dan menyarankan kepada pemerintah untuk membuat rancangan undang-undang untuk diajukan ke DPR RI, sehingga kekosongan hukum untuk masa yang akan datang sudah bisa dimonitor, baik penjual finance (pemilik barang), balai lelang maupun Pejabat Lelang Kelas II.

\section{C.SIMPULAN}

1. Pembeli lelang terbukti beritikat baik, dengan mengiktuti prosedur dan mekanisme lelang dan juga membayar Pendapatan Negara Bukan Pajak sesuai dengan Peraturan pemerintah nomor 1 tahun 2013, oleh karena Indonesia sebagai Negara hukum telah memberikan kepastian dan perlindungan hukum kepada pembeli lelang, yang kewenangannya dijalankan oleh Pejabat lelang.
2. Sebagai Negara hukum, Indonesia mengatur penjual bertanggung jawab terhadap barang miliknya yang akan dilelang guna memberikan jaminan kepastian hukum kepada pembeli, oleh karena itu Pejabat lelang pun tidak diberikan kewenangan untuk melelang barang-barang yang legalitasnya tidak sah, sebagaimana objek penelitian tersebut diatas. Untuk itu kiranya Penjual harus dibebani tanggung jawabnya guna memberikan ganti kerugian kepada pembeli barang lelang yang tidak dapat menguasai barang yang telah dibelinya dari lelang.

3. Dalam objek penelitian ini, karena pejabat lelang tidak melaksanakan kewajibannya, maka sebagai Negara hukum Pejabat lelang telah diatur oleh hukum guna memberikan jaminan kepastian hukum, karena pejabat lelang diberikan wewenang untuk meneliti legalitas dan dibenarkan untuk 
Khalidin, Perlindungan Hukum Terhadap Pembeli Barang Bergerak Yang Masih Terikat Fidusi...

menolak melelang jika legalitas formal tidak dipenuhi.

\section{D.SARAN}

1. Lelang merupakan jual beli khusus, memiliki spesifikasi hukum tertentu, yaitu penjualan barang dimuka umum, didahului dengan mengumpulkan peminat (pengumuman/ publikasi), dilakukan oleh dan dihadapan Pejabat Lelang Kelas II selaku perantara, penawaran harga dilakukan dengan cara lisan naik-naik, turun-turun dengan harga semakin menurun, tertulis dengan memasukkan penawaran dalam amplop tertutup dan pembeli harus mendapat perlindungan hukum, maka disarankan kepada Dewan Perwakilan Rakyat Republik Indonesia (DPR-RI) untuk membentuk Undang-Undang lelang yang dapat mengakomodir dan merangkum semua bidang lelang, sehingga secara spesifik dapat memberikan Jaminan Perlindungan hukum kepada
Pembeli barang bergerak terdaftar melalui lelang.

2. Dewan Perwakilan Rakyat Republik Indonesia (DPR-RI) dalam pembentukan UndangUndang lelang harus dapat merangkum dan mengakomodir semua bidang lelang dalam bentuk tanggung jawab Penjual kepada pembeli barang bergerak terdaftar yang tidak memperoleh hak-haknya pada umumnya sebagai pembeli.

3. Dewan Perwakilan Rakyat Republik Indonesia (DPR-RI) dalam pembentukan UndangUndang lelang, Perlu dicantumkan kewenangan dan jaminan kepastian hukum kepada Pejabat Lelang Kelas II, serta tanggung jawabnya apabila terjadi sengketa obyek lelang, oleh karena itu sebagai pejabat umum, harus diberikan kewenangan melelang barangbarang noneksekusi wajib, sehingga dapat meringankan beban pemerintah dalam bidang lelang.

\section{DAFTAR PUSTAKA}


Khalidin, Perlindungan Hukum Terhadap Pembeli Barang Bergerak Yang Masih Terikat Fidusi...

Purnama Tioria Sianturi, Perlindungan Hukum Terhadap Pembeli Barang Jaminan Tidak Bergerak Melalui Lelang, Edisi Revisi, Mandar Maju, Bandung, 2013.

Sadjijono, Bab-Bab Pokok Hukum Administrasi., Laks Bang PRESSindo, Yogyakarta, 2011.

Salim H.S., Perkembangan Hukum Jaminan Indonesia, PT. Raja Grafindo Persada, Jakarta, 2014.

Kamus Hukum Edisi Lengkap Bahasa Belanda Indonesia Inggris, Aneka Ilmu, Semarang, 1977.

Tiga Undang-Undang Dasar, Ghalia Indonesia, Jakarta, 1977.
Kitab Undang-Undang Hukum Perdata, Pradnya Paramita, Jakarta, 1982.

Kitab Undang-Undang Hukum Dagang dan Undang-undang Kepailitan, PT. Pradnya Paramita, Jakarta, 2003.

Himpunan Peraturan PerundangUndangan Republik Indonesia Menurut Sistem Engelbrecht, PT. Ichtiar Baru Van Hoeve, Jakarta, 2006.

Kumpulan Peraturan Tentang Lelang Tahun 2013, Kementerian Keuangan Republik Indonesia, Direktorat Jenderal Kekayaan Negara. 